TURNING POINT

\title{
Joel Rosenthal
}

\begin{abstract}
Joel Rosenthal, a chemist at the University of Delaware in Newark, was one of 30 young researchers in the United States to win a 2011 Ralph E. Powe Junior Faculty Enhancement Award, which provides research seed money. The award came in April from the Oak Ridge Associated Universities consortium, based in Tennessee.
\end{abstract}

\section{What was the first turning point in your career?}

I always thought I'd be a biologist, but as an undergraduate at New York University (NYU), I discovered a logic behind chemistry - its mechanisms and its quantitative nature - that I found compelling. Using the mechanisms underlying chemical reactions to build compounds and materials was like solving a puzzle. So I started studying organic chemistry. Then I heard Daniel Nocera, an inorganic chemist at the Massachusetts Institute of Technology (MIT) in Cambridge, give a seminar on molecular-level mechanisms of energy conversion. I realized that inorganic chemistry offered many more avenues for researching energy storage and release than did organic chemistry. During Dan's visit to NYU, he encouraged me to apply to MIT for my $\mathrm{PhD}$. I went on to study inorganic chemistry in his lab.

\section{Nocera's work drew media attention. What did that teach you?}

Dan has achieved a series of high-profile advances - most recently, an inexpensive solar cell dubbed the artificial leaf. I was in his lab when he first started to attract interest from the mainstream press, including the television news programme Nightline and the science show NOVA. I began to understand how important it is to communicate chemistry and energy research to the public. Dan's ability to break important problems into small yet meaningful advances was a big part of his success.

\section{What influenced your decision to accept a position at Delaware?}

This university and department are underrated. Delaware is putting lots of resources into equipment such as spectrometers and an advanced X-ray diffractometer. In the current economic climate, this is one of the few institutions that is significantly increasing its research programme and hiring faculty members. There is a great atmosphere in my department, with six young professors all building their research programmes and

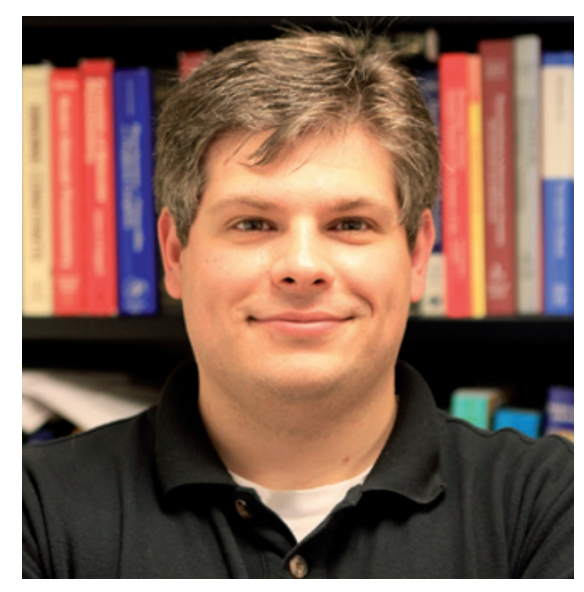

collaborating with one another and with senior colleagues.

You assembled a seven-member lab group in your first 18 months at Delaware. Do you worry about over-committing your resources through such fast growth?

It can be difficult to compete with established researchers when recruiting students, but I convinced a postdoc and six first-year graduate students to join me. I'm not worried; in fact, I'm looking to grow further. Society will suffer if scientists don't tackle capture and storage of energy. In my lab, we're trying to generate synthetic fuels by using nickel and palladium electrocatalysts to convert carbon dioxide into, for example, energy-rich carbon monoxide, which is a building block for fuels.

I hope that in the next five to six years, my team and others will have mapped out important molecular-design principles that will help us to design catalysts. I need as many people helping me as possible. The question is whether I bring in enough dollars to support them all. But being here - where costs are much lower than at MIT, for example - has made it easier to quickly establish a group.

What has been the biggest change in energy research in the past few years?

There is a much greater emphasis on applied science, which is important, but I hope that it will not consume the field. There are also more people coming in. We need scientists, but I also see people doing their same old research and wrapping it in an energy context to tap into funding, without trying to be innovative. We need paradigm-shifting fundamental research.

\section{INTERVIEW BY VIRGINIA GEWIN}

\section{UNITED KINGDOM}

\section{More visas for scientists}

As part of a policy overhaul, Britain has launched a visa scheme for 'exceptionally talented' people, including scientists. UK immigration policies were revised last year to reduce the number of migrant workers allowed in (see Nature 467, 491; 2010); the latest scheme came into effect on 9 August. The science portion will be administered by the Royal Society in London, which can recommend 300 researchers per year whose potential to become leaders in their fields is evidenced by major prizes or fellowships. Applicants need not be sponsored by an employer. Visas are valid for 40 months, after which visiting scientists may apply for a two-year extension, followed by possible settlement.

\section{EUROPEAN UNION}

\section{Industrial $\mathrm{PhD}$ launched}

The European Commission (EC) has created a pilot industrial- $\mathrm{PhD}$ programme to unite academia and businesses. The European Industrial Doctorates scheme will have $€ 20$ million (US\$28 million) to fund about 100 researchers until 2013, and aims to teach scientists how to combine scientific excellence with business skills. Participating PhD students at partner universities will spend at least half their time at a company in a different European Union (EU) state or associated country. Partner businesses will pay some expenses. EC policy coordinator Vanessa Debiais-Sainton says that the programme is likely to become a permanent part of the EU research-funding scheme Horizon 2020, set to launch in 2014.

\section{INNOVATION}

\section{Female inventors' prize}

A pilot award scheme aims to encourage scientific innovation and invention by women in the European Union (EU). The EU Prize for Women Innovators will award $€ 100,000$ (US\$142,000) for first place, $€ 50,000$ for second place and $€ 25,000$ for third. Applicants must be EU residents, have founded or co-founded a business before 2009 and have received EU funding. Entries will be judged on scientific merit and economic impact. Applications are open until 20 September. European Commission (EC) spokesman Mark English says that the EC hopes to inspire more women to commercialize their research. In future, the award criteria could change to emphasize research at an earlier stage of commercialization. 